\title{
A new Megatheriinae skull (Xenarthra, Tardigrada) from the Pliocene of Northern Venezuela - implications for a giant sloth dispersal to Central and North America
}

\author{
Alfredo A. Carlini, Diego Brandoni, \\ Rodolfo Sánchez, and Marcelo R. Sánchez-Villagra
}

\begin{abstract}
A skull of a ground sloth from the Pliocene San Gregorio Formation documents a northern neotropical occurrence of a megatheriine that addresses issues on intraspecific variation and biogeography. The new specimen is broadly similar in size and morphology to that of Proeremotherium eljebe from the underlying Codore Formation in the Urumaco Sequence, differing in several features such as a longer basicranial area and a more posteriorly projected basioccipital between the condyles. The living sloths species of Bradypus and Choloepus do not have unequivocal anatomical features that indicate sexual dimorphism. Nevertheless, fossil sloths may have shown such dimorphism, and speculations on this subject are part of the considerations that can be made when allocating fragmentary fossils (e.g., in the new skull the presence of a long sagittal crest could indicate a male individual and the absence of an extended crest in Proeremotherium eljebe a female one). We speculate that as early as the late middle Miocene, two main lines of Megatheriinae had clearly separated in two geographic areas, one in the rising Andean area and one at low latitudes on the lowlands of central and northern South America.
\end{abstract}

Alfredo A. Carlini. Lab. Morfología Evolutiva y Desarrollo (MORPHOS), División Paleontología de Vertebrados, Museo de La Plata, Facultad de Ciencias Naturales y Museo, Universidad Nacional de La Plata, Paseo del Bosque s/n, B1900FWA La Plata, Argentina and CONICET, Consejo Nacional de Investigaciones Científicas y Técnicas, Argentina acarlini@fcnym.unlp.edu.ar

Diego Brandoni. CONICET, Consejo Nacional de Investigaciones Científicas y Técnicas, Argentina and Laboratorio de Paleontología de Vertebrados, Centro de Investigaciones Científicas y Transferencia de Tecnología a la Producción (CICYTTP-CONICET), Materi y España, E3105BWA Diamante, Entre Ríos, Argentina, dbrandoni@cicyttp.org.ar

Rodolfo Sánchez. Museo Paleontológico de la Alcaldia de Urumaco, Falcon State, Venezuela. rodolfosanchez128@gmail.com Marcelo R. Sánchez-Villagra. Paläontologisches Institut und Museum, Universität Zürich, Karl-Schmid Strasse 4, CH-8006, Zürich, Switzerland. m.sanchez@pim.uzh.ch

Carlini, Alfredo A., Brandoni, Diego, Sánchez, Rodolfo, and Sánchez-Villagra, Marcelo R. 2018. A new Megatheriinae skull (Xenarthra, Tardigrada) from the Pliocene of Northern Venezuela - implications for a giant sloth dispersal to Central and North America. Palaeontologia Electronica 21.2.16A 1-12. https://doi.org/10.26879/771

palaeo-electronica.org/content/2018/2201-new-netropical-megatherinae

Copyright: May 2018 Palaeontological Association.

This is an open access article distributed under the terms of the Creative Commons Attribution License, which permits unrestricted use, distribution, and reproduction in any medium, provided the original author and source are credited.

creativecommons.org/licenses/by/4.0/ 
Keywords: Biogeography; Sexual dimorphism; Anatomy; Urumaco; Cenozoic; Proeremotherium; Eremotherium

Submission: 29 March 2017 Acceptance: 13 April 2018

\section{INTRODUCTION}

The Urumaco sequence, together with several geological formations in northwestern Venezuela, provides an almost continuous paleontological record for the last 20 million years (Sánchez-Villagra et al., 2010; Carrillo et al., 2015). This sequence includes the San Gregorio Formation (Pliocene), which has been in recent years prospected for fossil vertebrates, with the first fossil mammals described from it including rodents, carnivorans, notoungulates and xenarthrans (Vucetich et al., 2010; Castro et al., 2014; Forasiepi et al., 2014; Carrillo et al., 2018). These findings are particularly relevant as they provide the until now rare documentation of northern neotropical fossils from the time of the first phases of the GABI or Great American Biotic Interchange (Woodburne, 2010; Forasiepi et al., 2014; Carrillo et al., 2015; Amson et al., 2016). Here, we report on new skull of a ground sloth from the San Gregorio Formation that expands our knowledge of the northern South America Megatheriinae and its early dispersal to North America.

In Venezuela, Megatheriinae ground sloths are represented by Urumaquia robusta Carlini et al., 2006, from the Urumaco Formation (late Miocene); Proeremotherium eljebe Carlini et al., 2006, from the Codore Formation (Pliocene); and Eremotherium Spillmann, 1948, cf. E. laurillardi (Lund, 1842) from several late Pleistocene localities (e.g., Taima Taima, Muaco, Cucuruchú, Cañada Ocando, El Breal de Orocual, see Carlini et al., 2006, 2008a; Solórzano et al., 2015). Proeremotherium eljebe is of particular interest given several features that could indicate an ancestral or close relationship with the geographically-widespread megatheriine Eremotherium laurillardi (see Carlini et al., 2006). Eremotherium comprises three species: E. eomigrans De luliis and Cartelle, 1999, from the late Pliocene (Blancan) of USA; E. sefvei De luliis and St-André, 1997, from the Pleistocene of Bolivia, and E. laurillardi from several late Pleistocene localities of North America (e.g., southern Mexico and west coast of USA up to South Carolina), Central America and low latitudes of South America (e.g., Brazil, Ecuador, Colombia, Venezuela) (but see Faure et al., 2014). In the study of
Megatheriinae, it is relevant to consider that the upper dental series comprises five teeth with a molar shape, usually called molariforms (see Cartelle and De luliis, 2006; Brandoni et al., 2017).

\section{Geological Setting}

The Megatheriinae new skull (mentioned as "new Megatheriidae indet." in Vucetich et al., 2010) comes from a locality in northwestern Venezuela, Falcón State (Figure 1). The outcrops are mostly of neogene deposits, mainly representing a coastal shallow marine environment (Johnson et al., 2009), but continental levels are present (Vucetich et al., 2010). The sediments of San Gregorio Fm. are composed mainly of mudstones and limestones, with intercalations of sandstones and pebbly conglomerates (Quiroz and Jaramillo, 2010; Vucetich et al., 2010), with a total of more than $300 \mathrm{~m}$ at the type section (Ministerio de Energía y Minas, 1997). Recent paleontological studies of this formation described invertebrates (e.g., molluscs, crustaceans, foraminiferans) from the overlaying marine Cocuiza Member (Hambalek et al., 1994; Aguilera et al., 2010; Mihaljević et al., 2010). From its basal Vergel Member, crocodylians (Crocodylus falconensis, in Scheyer et al., 2013), caviomorph rodents (Cardiatherium sp. and cf. Caviodon, Neoepiblema sp., and Marisela gregoriana, in Vucetich et al., 2010), carnivoran procyonids (Cyonasua sp., in Forasiepi et al., 2014), toxodonts (Carrillo et al., 2018) and xenarthran cingulates (Pliodasypus vergelianus, in Castro et al., 2014) have been described. Also from the same locality of Vergel Member in which we found the specimen reported here are mentioned turtles, osteoderms of a new species of the Glyptodontinae Boreostemma ( $B$. aff. codorensis) and remains of Pampatheriidae tentatively referred to aff. Holmesina floridanus (Carlini and Zurita, 2010; Zurita et al., 2011; Scheyer et al., 2013; Castro et al., 2014). The new skull here described is part of the collections of the Museo Paleontológico de Urumaco, Estado Falcón, Venezuela (AMU-CURS).

The age of the San Gregorio Formation is estimated to be late Pliocene / early Pleistocene (Ministerio de Energía y Minas, 1997) by stratigraphical correlation. This estimated age is concor- 


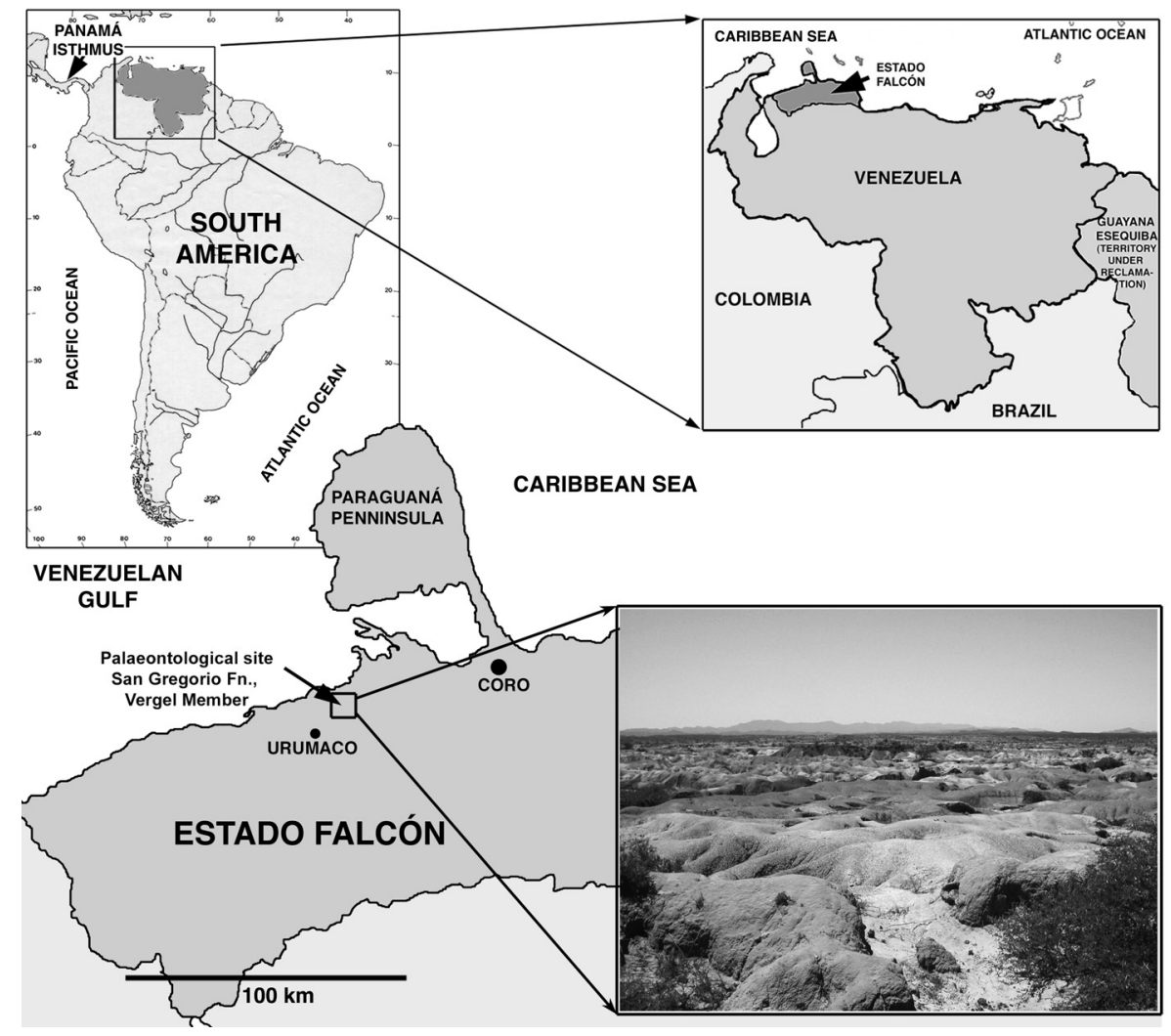

FIGURE 1. Location map showing the locality where the AMU-CURS 184 specimen was recovered from San Gregorio Fm. outcrops.

dant with the biochronologic assessment derived of the tentative assignation of osteoderms of a pampathere collected from the lower Vergel member (Carlini and Zurita, 2010), a taxon recorded in the Blancan of USA (4.9 Ma to 1.8 Ma).

\section{SYSTEMATIC PALEONTOLOGY}

MAMMALIA Linnaeus, 1758

XENARTHRA Cope, 1889

TARDIGRADA Latham and Davies in Forster, 1795

MEGATHERIIDAE Gray, 1821

MEGATHERIINAE Gray, 1821

PROEREMOTHERIUM Carlini, Brandoni and

Sánchez, 2006

Type species. Proeremotherium eljebe Carlini, Brandoni and Sánchez, 2006.

Geographic and stratigraphic distribution. Estado Falcón, Urumaco; El Jebe Member, Codore Formation and Vergel Member, San Gregorio Formation, Pliocene of Venezuela.

\section{cf. Proeremotherium}

Referred material. AMU-CURS 184, an almost complete skull lacking mandible, jugals, the pre- maxillae, the left zygomatic process of the squamosal, vertical lamina of the left pterygoid, anterior part of the nasals, anterior part of the maxillae, lateral and partial anterior wall of the alveoli of right M1 and lateral and anterior wall of the alveoli of left $M 1$, the lateral wall of those of the left tooth row, and teeth (Figure 2).

Geographic and stratigraphic provenance. Twelve Km NNW from Urumaco town; Falcón Basin, Vergel Member, lower levels of San Gregorio Formation, late Pliocene.

\section{Description}

The skull AMU-CURS 184 is similar in size and gross morphology to that of Proeremotherium eljebe (represented by the type specimen AMUCURS 126) (Figure 2, Table 1). Similarly to Proeremotherium eljebe, Eremotherium laurillardi and $E$. eomigrans, AMU-CURS 184 is relatively low (mainly at the anterior third), elongate and "gracile" in comparison with the Pleistocene Megatherium Cuvier, 1796, species; with its major width on both the maxillar and the squamosal zygomatic roots (Figure 3). The basicranial area is longer than in $P$. 


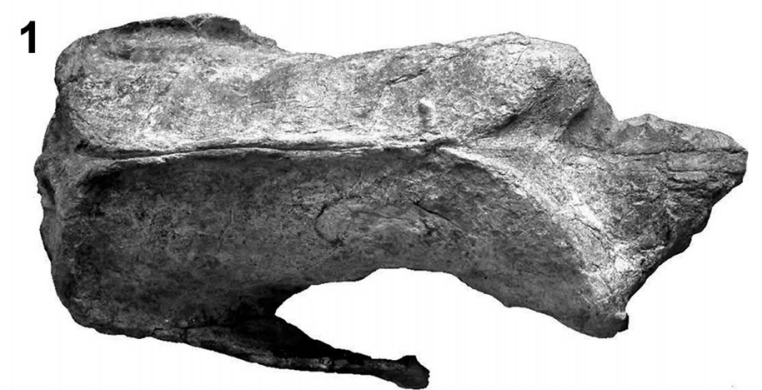

3
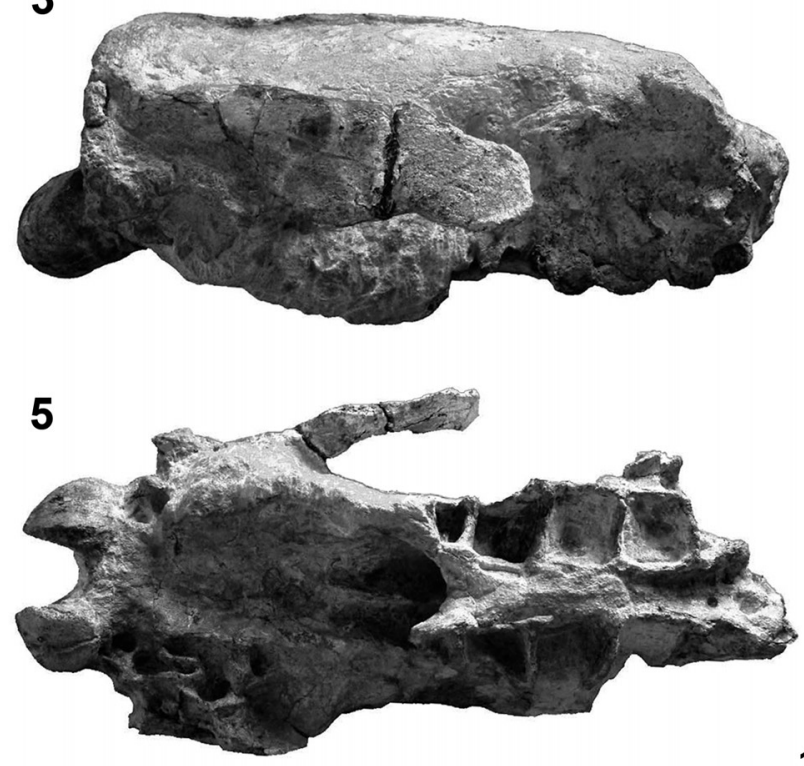

\section{cf. Proeremotherium AMU-CURS 184}

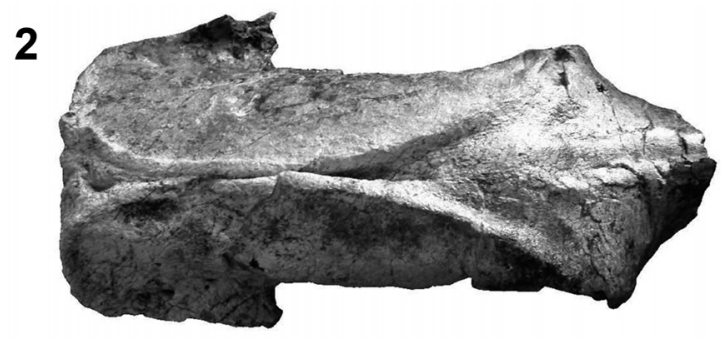

4

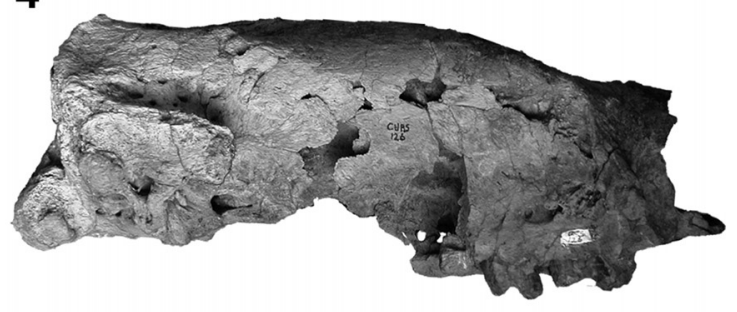

6

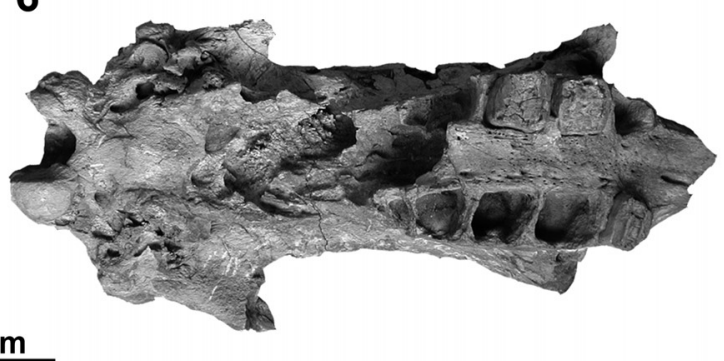

Proeremotherium eljebe

FIGURE 2. Skulls of AMU-CURS 184 and AMU-CURS 126 (Proeremotherium eljebe type specimen). AMU-CURS 184 in 1, dorsal; 3, lateral, and 5, palatal views. Proeremotherium eljebe in 2, dorsal; 4, lateral, and 6, palatal views.

eljebe, and the basioccipital is more posteriorly projected relative to the condyles. The antero-dorsal and postero-dorsal edges of each temporal fossa are convex both anteriorly and posteriorly, respectively, and the edge were both fossa converge at midline is straight and form a longer sagittal crest than that of $P$. eljebe. Because of the latter, in AMU-CURS 184 sagittal crest starts just poste-

TABLE 1. Approximate cranial measurements of the type specimen of Proeremotherium eljebe and cf. Proeremotherium (AMU-CURS 184).

\begin{tabular}{lcc}
\hline & $\begin{array}{c}\text { Proeremotherium eljebe } \\
\text { Type AMU-CURS 126 }\end{array}$ & $\begin{array}{c}\text { cf. Proeremotherium } \\
\text { AMU-CURS 184 }\end{array}$ \\
\hline Preserved length & $460 \mathrm{~mm}$ & $455 \mathrm{~mm}$ \\
Occipital width & $160 \mathrm{~mm}$ & $168 \mathrm{~mm}$ \\
Bi-condylar width & $97 \mathrm{~mm}$ & $108 \mathrm{~mm}$ \\
Palatal width at M2 tooth & $33 \mathrm{~mm}$ & $30 \mathrm{~mm}$ \\
Alveolus of M2 (w $\times \mathrm{l})$ & $29 \mathrm{~mm} \times 30 \mathrm{~mm}$ & $31 \mathrm{~mm} \times 32 \mathrm{~mm}$ \\
Alveolus of M3 $(w \times l)$ & $30 \mathrm{~mm} \times 32 \mathrm{~mm}$ & $32 \mathrm{~mm} \times 36 \mathrm{~mm}$ \\
Alveolus of M4 $(w \times l)$ & $28 \mathrm{~mm} \times 26 \mathrm{~mm}$ & $31 \mathrm{~mm} \times 29 \mathrm{~mm}$ \\
Alveolus of M5 $(w \times l)$ & Not preserved & $14 \mathrm{~mm} \times 18 \mathrm{~mm}$ \\
\hline
\end{tabular}



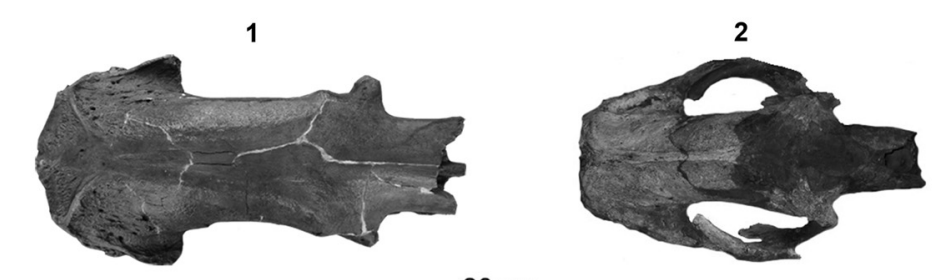

3

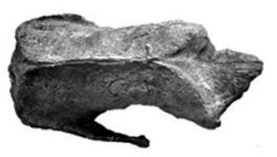

$20 \mathrm{~cm}$

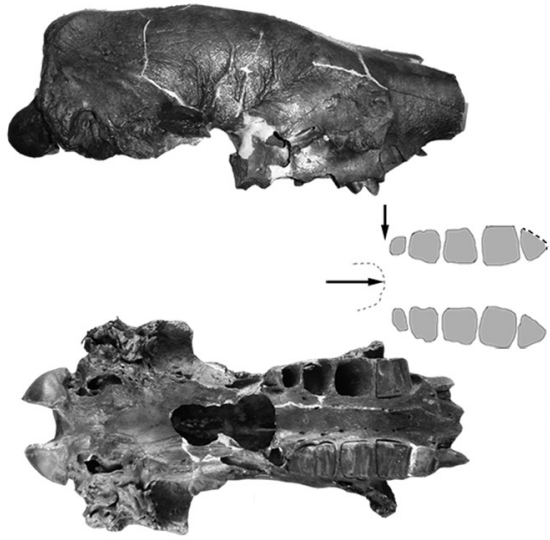

Eremotherium laurilliardi UCV-1175

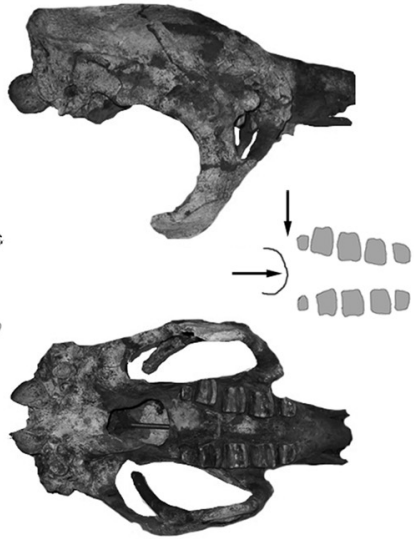

Eremotherium eomigrans UF 206879
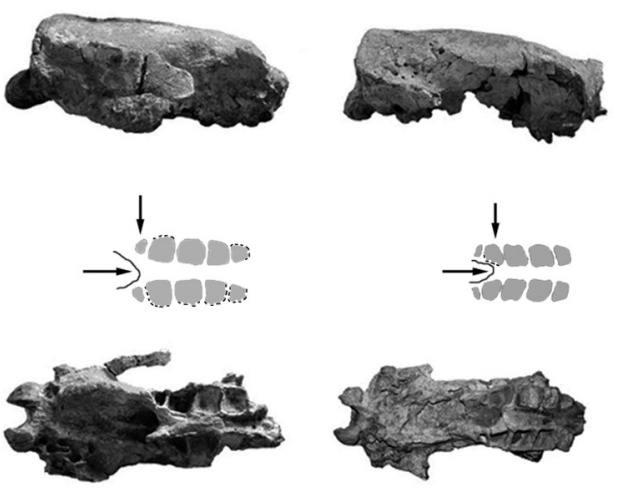

cf. Proeremotherium AMU-CURS 184

Proeremotherium eljebe AMU-CURS 126 Type

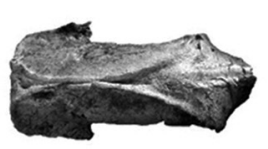

FIGURE 3. Skulls of 1: Eremotherium laurillardi, 2: Eremotherium eomigrans, 3: AMU-CURS 184, cf. Proeremotherium sp., and 4: Proeremotherium eljebe (AMU-CURS 126, type), compared in (from top to bottom) dorsal, lateral and palatal views. In light grey are the upper dental series alveoli contours of each skull; black arrows shows the outline and extension of the posterior palatal notch, and up to where it reaches in relation to the dental series (in 1 the dotted line is used because that part of the palatal notch was mechanically broken).

rior to the level of the maxillar zygomatic root (anteriorly to the interorbital constriction), whereas in Proeremotherium eljebe, the margins converge posteriorly, at the anterior edge of the squamosal zygomatic root, and consequently form a shorter sagittal crest. The dorsal margin of the skull of AMU-CURS 184 is slightly convex at the middle third, but abruptly descends at the fronto-nasal level, where a sub-triangular concave area is present (with a side parallel to a transverse plane and its opposite angle pointed posteriorly); in P. eljebe the triangular area is much more extended and almost convex, and in the species of Eremotherium it is almost flat; in Proeremotherium eljebe and Eremotherium laurillardi the fronto-nasal area descends gradually antero-ventrally. As in $P$. eljebe, E. laurillardi and E. eomigrans, AMU-CURS 184 has an occiput forming a ca. $90^{\circ}$ angle, either with the parietal dorsal plane of the skull roof and the palatal plane (different to the species of Megatherium were the angle with de palatal plane is close to $70^{\circ}$ ). As in E. laurillardi and E. eomigrans, AMU-CURS 184 has the occipital condyles posteriorly projected, hemispherical in lateral view, and bigger and with an antero-posterior axis more sub-horizontal than in P. eljebe. As in P. eljebe, $E$. laurillardi, and $E$. eomigrans, the basilar plane of AMU-CURS 184 is close to the palatal plane, surely related to the low hypsodonty reached (not as in Megatherium species where it is higher, as do the hypsodonty, see De luliis, 1996:154). In AMUCURS 184, the maxillar zygomatic root is located lateral to M2, whereas in Proeremotherium eljebe lies a little more posterior, extending between the mid plane of the M2 and the mid plane of the M3. The infraorbital foramen is at $24 \mathrm{~mm}$ above the alveolar plane, whereas it is at $22 \mathrm{~mm}$ in $P$. eljebe. The abundant remains of Eremotherium laurillardi and Megatherium americanum Cuvier, 1796, indicate that both the position of the root and the height of the infraorbital foramen could vary somewhat. In Eremotherium laurillardi the root tends to lies more anteriorly, extending from the level of the middle of M1 to that of the middle of M3; whereas in $M$. americanum, the position of the root is more variable than in Eremotherium laurillardi (see De luliis, 1996). In AMU-CURS 184, because the height of the squamosal zygomatic root, it is more 
dorsally extended and is higher than in P. eljebe. As in other megatheriines, the squamosal part of the zygomatic arch is a laminar vertical bone over the alveolar plane, but its ventral margin is sub-horizontal as in Proeremotherium eljebe and Eremotherium species (not oblique as in Megatherium species), and its anterior end reaches the level of the M4-M5 septum. The preserved palatal premolariform extension is concave, as is at the M1-M2 area, but is almost flat at the M3-M4. The posterior palatal notch is U-shaped, and its anterior margin is at the M5 level; whereas in P. eljebe it is anteriorly extended reaching the mid M4 level, and in Eremotherium laurillardi and Megatherium americanum, the position of the posterior palatal notch is variable (see De luliis, 1996), but always posterior to the M5 level.

The upper dental series (M1-M5) has approximately $165 \mathrm{~mm}$ in length. Each tooth row is convex on its lingual margin and straight-convex on the labial margin, whereas in $P$. eljebe the margins are much more straight either lingual/labial side (Figure 3). The maximum distance between the alveolus of both tooth rows is between the preserved anterior most margin the $\mathrm{M} 1(43 \mathrm{~mm})$ and the middle plane of the M5 $(49 \mathrm{~mm})$. Despite the fact that the specimen AMU-CURS 184 does not preserve the molariform teeth, judging from the shape of the alveoli, we hypothesize that the M1 is subtrapezoidal, the M2-M4 are sub-squared, and the M5 (the smallest) is mesiodistally compressed (as in other Megatheriinae), and nearly oval in outline.

\section{DISCUSSION}

Intraspecific variation has been considered in studies of Tardigrada (e.g., McDonald, 1995; De Iuliis, 1996; Esteban, 1996; White and MacPhee, 2001; Brandoni et al., 2010). There are many factors that could lead to variation, including genetic, environmental and dietary factors, ontogenetic stage of the specimen and sexual dimorphism. With regard to sexual dimorphism, studies in living sloths such as Bradypus torquatus Illiger, 1811, indicate the existence of sexual dimorphism in body mass (females heavier than males) (see Lara-Ruiz and Chiarello, 2005; Chiarello, 2008). Fossil sloths do not have unequivocal anatomical features that indicate sexual dimorphism, as in living sloth Bradypus and Choloepus (Figure 4). Nevertheless, some speculations about extinct sloths have been made on the basis of cranial morphology (e.g., Cartelle and Bohórquez, 1982; De luliis, 1996; McDonald, 1995, 2006; Miño-Boilini and
Zurita, 2015) and postcranial features (Amson et al., 2015a, 2015b). For Eremotherium laurillardi, Cartelle and Bohórquez (1982) and De luliis (1996), considered that variation in the temporal region of the skull could be explained by sexual dimorphism. A consideration of differences in other areas of the skull would also be important to assess this important matter. Although the assignation to a specific sex seems to be difficult (see McDonald and Lundelius, 2009, p. 408), De lullis (1996) suggested that a larger skull and a more prominent sagittal crest are male features. We agree that it occurs in different groups of mammals, and add that the ontogenetic age of the specimens can also influence the occurrence and size of such crest (e.g., Carnivora). For scelidotheres, Miño-Boilini and Zurita (2015) suggested that specimens with sagittal crest are males, and specimens lacking sagittal crest are females, but again the ontogenetic stage of the specimens is also a factor to consider.

As we stated above, the AMU CURS 184 skull shares some features with $P$. eljebe (e.g., size, general shape of the skull), but differs in others (e.g., anterior palatal notch extension, position and size of the occipital condyles, position and height of the squamosal zygomatic arch, shape of the temporal crests). If sexual dimorphism is present in megatheriines as is sustained by different authors (e.g., Cartelle and Bohórquez, 1982; De luliis, 1996) and considering their arguments, in AMUCURS 184 the presence of a long sagittal crest could indicate a male individual, and the absence of an extended crest in Proeremotherium eljebe a female one, but given the lack of at least two specimens from the same stratigraphic level, the idea of sexual dimorphism is at this point mere speculation. Should new material justify the erection of a new species to include AMU CURS 184, this discussion would be in part clarified.

The Megatheriinae assemblage of Urumaco sequence. Among the Urumaco tardigrades, the first Megatheriinae from the Cenozoic of Venezuela were described by Carlini et al. (2006), represented by two new genera and species from the late Miocene - Pliocene. For the Urumaco Formation (late Miocene), Urumaquia robusta was described based on few but significant remains (see Carlini et al., 2006), that were collected in the Urumaco outcrops in the 1970s; subsequently, Carlini et al. (2008a) improved the knowledge of this taxon by describing and comparing new remains. 

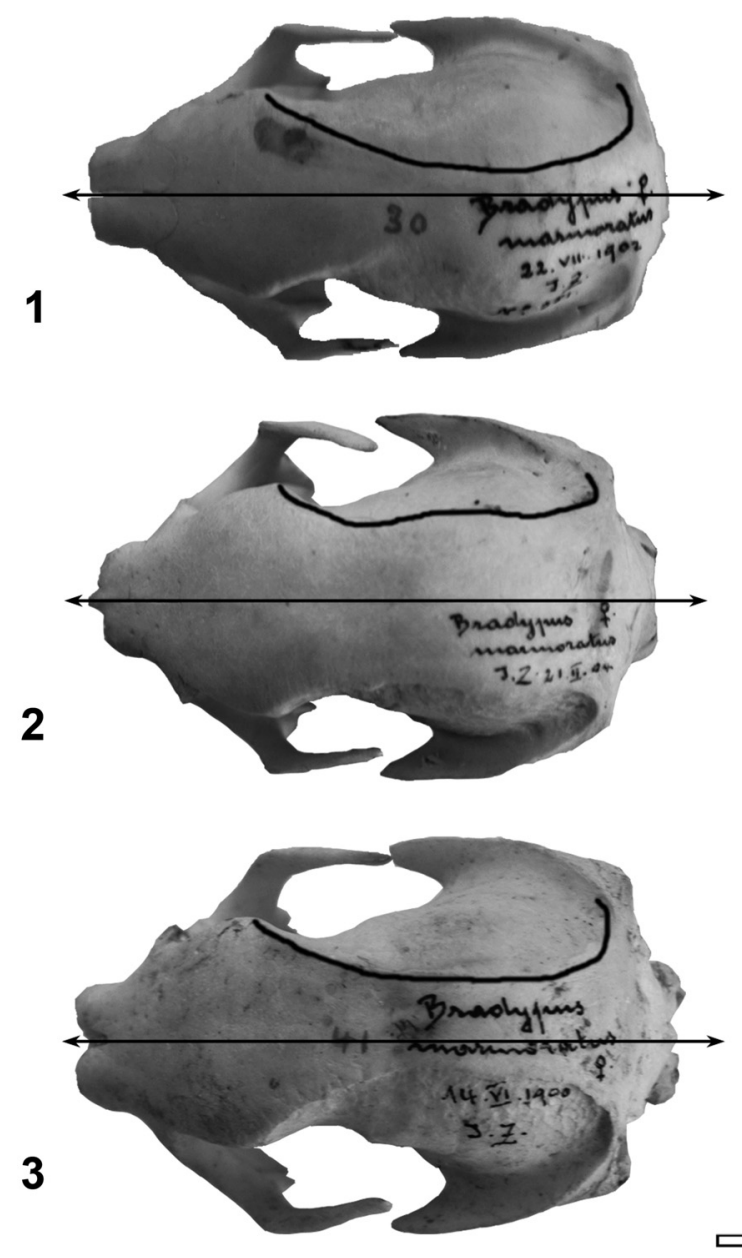

$2 \mathrm{~cm}$

FIGURE 4. Skulls of Bradypus marmoratus (sic) of the PIMUZ comparative collection in dorsal view; females on the left and males on the right, in three different sutural ages: 1 and 4, young adults (with most of the posterior sutures opened); 2 and 5, adults (with most of the posterior sutures closed but visible); and, 3 and 6, old adults (with most of the posterior sutures closed and not visible). In all the skulls the right temporal line was marked with a black line showing a great variation among sexes and ages.

For the Codore Fm. (Pliocene) Proeremotherium eljebe was described based on an almost complete skull (Figure 2), and was originally interpreted to be phylogenetically close to Eremotherium species, because it shows characters (e.g., lower basilar plane, low hypsodonty) (Figure 3) that we could expect in an "ancestral form" or sister group close to Eremotherium lineage. A phylogenetic analysis is pending and is not the intention of this contribution.

Eremotherium is mainly a Quaternary megatheriine genus distributed almost exclusively at low latitudes of North America, Central America and South America (Pujos and Salas, 2004; Cartelle and De luliis, 2006; Tito, 2008; McDonald and Lundelius, 2009), and is recognizable by its large size, by the triangular shape of the predental part of its rostrum and by its lower positioned basilar plane and condyles (with respect to the palatal plane) than in the Megatherium species. Eremotherium eomigrans and $E$. laurillardi were proposed as forming a phyletic sequence (De luliis and Cartelle, 1999); this sequence could have begun in the Pliocene of Venezuela with $P$. eljebe. The new remains described in this paper from San Gregorio Fm. (late Pliocene) and that we refer tentatively to Proeremotherium, show differences on its basicranial, temporal and dental morphology, and the size and proportions with $P$. eljebe (compare in Figure 2 ), but share with it the general appearance, the height relation between the palatal and basicranial 
planes, profile and low hypsodonty degree (Figures 2 and 3 ).

Carlini et al. (2006, 2008a) considered the possibility that a species morphologically close to Proeremotherium eljebe migrated into North America and gave rise to the early species of Eremotherium (i.e., E. eomigrans from the Blancan, latest Pliocene- middle Pleistocene). The record of AMUCURS 184 from the San Gregorio Formation is consistent with that hypothesis, because it seems to be morphologically intermediate between Proeremotherium eljebe and Eremotherium eomigrans (see Figure 3). After the cladogenetic process of Eremotherium giving rise to $E$. laurillardi in the Rancholabrean (late Pleistocene) of North America, E. laurillardi migrated to South America and colonized most of the north and central lowlands of South America (Carlini et al., 2008a). This biogeographic scenario proposed for northern megatheriines, i.e., migration from South America during the $\mathrm{mid} /$ late Pliocene, dispersion and diversification into North America and re-ingression into South America during the latest Pleistocene, was also proposed for pampatheres (Scillato-Yané et al., 2005), glyptodonts (Carlini et al., 2008b; Carlini and Zurita, 2010; Zurita et al., 2011) and dasypodids (Castro et al., 2014), breaking with the traditional assumption that the GABI for the xenarthrans was a unidirectional process in which they simply dispersed from South America to North America and an ulterior diversification happened there.

Xenarthrans were one of the most successful South American mammals participating in the GABI, given that Tardigrada and Cingulata reached and diversified in North America (McDonald, 2005; Carlini et al., 2008a, 2008c; Carlini and Zurita, 2010). There are records of South American taxa at 4.7 to $3.6 \mathrm{Ma}$ in Mexico (Carranza- Castañeda and Miller, 2004; Flynn et al., 2005). The main phase (in terms of diversity and frequency of findings of xenarthrans) of GABI began ca. 2.7 Ma, as it represents the oldest records of continuous bidirectional flux of land mammals without a marked selectivity.

Concerning the diversity and dispersal paths followed by Megatheriinae, overviews of the megatheriine remains of the late Cenozoic of South America and their geographic and temporal distribution (Carlini et al., 2002, 2006) show that the Cenozoic findings are not frequent at low latitudes. The new megatheriines of the Urumaco sequence not only extended the knowledge of their diversity in South America, but they lead us to speculate about the moment of differentiation of Megatherium and Eremotherium, both genera with maximum diversity in the Pleistocene. Concerning Urumaquia robusta, of similar size (or even larger in some respects) than the late Miocene-Pliocene Argentinean species of Pyramiodontherium Rovereto, 1914, and Megatheriops C. Ameghino and Kraglievich, 1921, it is clear that some of its morphological features are derived with respect to those of the taxa from the middle Miocene of Argentina. The taxa recorded in the middle Miocene of La Venta, Colombia, were very likely the smallest and most gracile Megatheriinae at the time (see Hirschfeld, 1985; Carlini et al., 2006) and with a greater number of plesiomorphic characters than those of the fauna from Venezuela. The phylogenetic relationships among these middle to late Miocene megatheriines need to be investigated, but based on the known records we could speculate that as early as the latest middle Miocene, two main lines of Megatheriinae are clearly separated in two geographic areas: one in the rising Andean (on western high to low latitudes, represented by Megathericulus, Eomegatherium, Pyramiodontherium -see Brandoni et al., 2017) and one at low latitudes on the lowlands of central and northern South America, the latter documented in the La Venta and Urumaco deposits of Colombia and Venezuela (represented by Urumaquia, Proeremotherium, Eremotherium -see Carlini et al., 2008a). However, some megatheriines sloths may have had a wide latitudinal distribution across the continent, e.g., Pliomegatherium lelongi (see Amson et al., 2016) or even Eremotherium laurillardi (Cartelle and De luliis, 1995).

The vertebrate faunas coming from the successive Socorro, Urumaco, Codore and San Gregorio Formations are different between each other. However, we can recognize a process of speciation along the different xenarthran lineages recognized (e.g., mylodontoids, megatherioids, glyptodontoids). Notwithstanding, the overlying continental San Gregorio fauna is radically different to all the previous three: the crocodylians include the first and oldest record of a group in that area (Scheyer et al., 2013) and, many groups of mammals are novel, including the first record of North American procyonid immigrants from the northern half of the continent (Forasiepi et al., 2014).

\section{ACKNOWLEDGMENTS}

We thank the constructive suggestions from the two anonymous reviewers and the editor $\mathrm{C}$. Haug, J. Carrillo-Briceño for assistance in the field 
and in the laboratory, G. Aguirre and A. Wegmann for technical help and the Instituto del Patrimonio
Cultural de Venezuela and the local authorities for hospitality and permission to work in Urumaco.

\section{REFERENCES}

Aguilera, O.A., Rodrigues de Aguilera, D., Vega, F., and Sánchez-Villagra, M.R. 2010. Mesozoic and Cenozoic decapod crustaceans from Venezuela and related trace-fossil assemblages, $p$. 103-128. In Sánchez-Villagra, M.R., Aguilera, O.A., and Carlini, A.A. (eds.), Urumaco and Venezuelan Paleontology - The Fossil Record of the Northern Neotropics. Indiana University Press, Bloomington and Indianapolis.

Ameghino, C. and Kraglievich, L. 1921. Descripción del Megatherium gallardoi C. Amegh. descubierto en el pampeano inferior de la ciudad de Buenos Aires. Anales del Museo Nacional de Historia Natural de Buenos Aires, 31:134-156.

Amson, E., Argot, C., McDonald, H.G., and de Muizon, C. 2015a. Osteology and functional morphology of the forelimb of the marine sloth Thalassocnus (Mammalia, Tardigrada). Journal of Mammalian Evolution, 22:169-242. https://doi.org/10.1007/s10914-014-9268-3

Amson, E., Argot, C., McDonald, H,G., and de Muizon, C. 2015b. Osteology and functional morphology of the hind limb of the marine sloth Thalassocnus (Mammalia, Tardigrada). Journal of Mammalian Evolution, 22:355-419. https://doi.org/10.1007/s10914-014-9274-5

Amson, E., Carrillo, J.D., and Jaramillo, C. 2016. Neogene sloth assemblages (Mammalia, Pilosa) of the Cocinetas Basin (La Guajira, Colombia) implications for the Great American Biotic Interchange. Palaeontology, 59:563-582. https://doi.org/10.1111/pala.12244

Brandoni, D., Carlini, A.A., Anaya, F., Gans, P., and Croft, D.A. 2017. New remains of Megathericulus patagonicus Ameghino, 1904 (Xenarthra, Tardigrada) from the Serravallian (Middle Miocene) of Bolivia; chronological and biogeographical implications. Journal of Mammalian Evolution https://doi.org/10.1007/s10914-017-9384-y

Brandoni, D., Ferrero, B.S., and Brunetto, E. 2010. Mylodon darwini Owen (Xenarthra, Mylodontinae) from the late Pleistocene of Mesopotamia, Argentina. 2010. Remarks on individual variability, paleobiology, paleobiogeography, and paleoenvironment. Journal of Vertebrate Paleontology, 30:1547-1558. https://doi.org/10.1080/02724634.2010.501449

Carlini, A.A., Brandoni, D., and Sánchez, R. 2006. First Megatheriines (Xenarthra, Phyllophaga, Megatheriidae) from the Urumaco (Late Miocene) and Codore (Pliocene) Formations, Estado Falcón, Venezuela. Journal of Systematic Paleontolology, 4:269-278. https://doi.org/10.1017/ S1477201906001878

Carlini, A.A., Brandoni, D., and Sánchez, R. 2008a. Additions to the knowledge of Urumaquia robusta (Xenarthra, Phyllophaga, Megatheriidae) from the Urumaco Formation (Late Miocene), Estado Falcón, Venezuela. Palaeontologische Zeitschrift, 82:153-162. https:// doi.org/10.1007/BF02988406

Carlini, A.A., Brandoni, D., Scillato-Yané, G.J., and Pujos, F. 2002. Una nueva especie de megaterino (Xenarthra, Megatheriidae) del Mioceno Tardío-Plioceno de Catamarca, Argentina. Ameghiniana, 39:367-377.

Carlini, A.A. and Zurita, A.E. 2010. An introduction to cingulate evolutionary history during the Great American Biotic Interchange: biogeographical clues from Venezuela, p. 233-255. In Sánchez-Villagra MR, Aguilera OA, and Carlini AA (eds.), Urumaco and Venezuelan Paleontology - the Fossil Record of the Northern Neotropics. Indiana University Press, Bloomington and Indianapolis.

Carlini, A.A., Zurita, A.E., and Aguilera, O.A. 2008b. North American glyptodontines (Xenarthra, Mammalia) in the upper Pleistocene of northern South America. Palaeontologische Zeitschrift, 82:125-138. https://doi.org/10.1007/BF02988404

Carlini, A.A., Zurita, A.E., Scillato-Yané, G.J., Sánchez, R., and Aguilera, O.A. 2008c. New glyptodont from the Codore Formation (Pliocene), Falcón State, Venezuela, its relationship with the Asterostemma problem, and the paleobiogeography of the Glyptodontinae. Palaeontologische Zeitschrift, 82:139-152. https://doi.org/10.1007/BF02988405

Carranza-Castañeda, O. and Miller, W.E. 2004. Late Tertiary terrestrial mammals from Central Mexico and their relationship to South American immigrants. Revista Brasileira de Paleontologia, 7:249-261.

Carrillo, J.D., Forasiepi, A.M., Jaramillo, C., and Sánchez-Villagra, M.R. 2015. Neotropical mammal diversity and the Great American Biotic Interchange: spatial and temporal variation 
in South America's fossil record. Frontiers in Genetics, 5:1-11. https://doi.org/10.3389/ fgene.2014.00451

Carrillo, J.D., Amson, E., Jaramillo, C., Sánchez, R., Quiroz, L., Cuartas, C., Rincón, A.F., and Sánchez-Villagra, M.R. 2018. The Neogene Record of Northern South American Native Ungulates. Smithsonian Contributions to Palaeobiology. In press.

Cartelle, C. and Bohórquez, G.A. 1982. Eremotherium laurillardi (Lund, 1842). Parte I. Determinação específica e dimorfismo sexual. Iheringia Série Geologia, 7:45-63.

Cartelle, C. and De luliis, G. 1995. Eremotherium laurillardi: The Panamerican late Pleistocene megatheriid sloth. Journal of Vertebrate Paleontology, 15: 830-841. https://doi.org/10.1080/ 02724634.1995.10011265

Cartelle, C. and De luliis, G. 2006. Eremotherium laurillardi (Lund) (Xenarthra, Megatheriidae), the Panamerican giant ground sloth: taxonomic aspects of the ontogenetic development of skull and dentition. Journal of Systematic Paleontology, 4:199-209. https://doi.org/10.1017/ S1477201905001781

Castro, M.C., Carlini, A.A., Sánchez, R., and Sánchez-Villagra, M.R. 2014. A new Dasypodini armadillo (Xenarthra: Cingulata) from San Gregorio Formation, Pliocene of Venezuela: affinities and biogeographic interpretations. Naturwissenschaften, 101:77-86. https://doi.org/ 10.1007/s00114-013-1131-5

Chiarello, A.G. 2008. Sloth ecology: an overview of field studies, p. 269-280. In Vizcaíno, S.F. and Loughry, W.J. (eds.), The Biology of the Xenarthra. University Press of Florida, Gainesville.

Cope, E.D. 1889. The Edentata of North America. American Naturalist, 23:57-664.

Cuvier, G. 1796. Notice sur le squelette d'une très grande espèce de quadrupède inconnue jusqu'à présent trouvé au Paraguay et déposé au cabinet d'histoire naturelle de Madrid. Magasin Encyclopédique: ou Journal des Sciences, des Lettres et des Arts, 1:303-310.

De luliis, G. 1996. A Systematic Review of the Megatheriinae (Mammalia: Xenarthra: Megatheriidae). Unpublished Ph.D. Thesis, University of Toronto, Toronto, Canada.

De luliis, G. and Cartelle, C. 1999. A new giant megatheriine ground sloth (Mammalia: Xenarthra: Megatheriidae) from the Late Blancan to Early Irvingtonian of Florida. Zoological Journal of the Linnean Society, 127:495-515. https://doi.org/10.1111/j.10963642.1999.tb01383.x

De luliis, G. and Saint-André, P.A. 1997. Eremotherium sefvei nov. sp. (Mammalia: Xenarthra: Megatheriidae) from Pleistocene of Ulloma, Bolivia. Geobios, 30:453-461. https://doi.org/ 10.1016/S0016-6995(97)80210-0

Esteban, G. 1996. Revisión de los Mylodontinae cuaternarios (Edentata, Tardigrada) de Argentina, Bolivia y Uruguay. Sistemática, Filogenia, Paleobiología, Paleozoogeografía y Paleoecología. Unpublished Ph.D. Thesis, Facultad de Ciencias Naturales e Instituto Miguel Lillo, Tucumán, Argentina.

Faure, M., Guérin, C., and Parenti, F. 2014. Sur l'existence de deux espèces d'Eremotherium, $E$. rusconii (Schaub, 1935) et E. laurillardi (Lund, 1842), dans le Pléistocène supérieur du Brésil intertropical. Comptes Rendus Palevol, 13:259-266. https://doi.org/10.1016/ j.crpv.2013.11.001

Flynn, J.J., Kowallis, B.J., Núñez, C., Carranza-Castañeda, O., Miller, W.E., Swisher III, C.C., and Lindsay, E. 2005. Geochronology of Hemphillian-Blancan aged strata, Guanajuato, Mexico, and implications for timing of the Great American Biotic Interchange. Journal of Geology, 113:287-307.

Forasiepi, A.M., Soibelzon, L.H., Suárez Gómez, C., Sánchez, R., Quiroz, L.I., Jaramillo, C., and Sánchez-Villagra, M.R. 2014. Carnivorans at the Great American Biotic Interchange: new discoveries from the northern Neotropics. Naturwissenschaften, 101:965-974. https://doi.org/ 10.1007/s00114-014-1237-4

Gray, J.E. 1821. On the natural arrangement of vertebrose animals. London Medical Repository, 5:296-310.

Hambalek, N., Rull, V., De Digiacomo, E., and Díaz de Gamero, M.L. 1994. Evolución paleoecológica y paleoambiental de la secuencia del Neogeno en el surco de Urumaco. Estudio palinológico y litológico. Boletín de la Sociedad Venezolana de Geología, 19:7-19.

Hirschfeld, S.E. 1985. Ground sloths from the Friasian La Venta fauna, with additions to the PreFriasian Coyaima fauna of Colombia, South America. University of California Publications, Geological Sciences, 128:1-91. 
Johnson, K.G., Sánchez-Villagra, M.R., and Aguilera, O. 2009. The Oligocene/Miocene transition on coral reefs in the Falcón Basin (NW Venezuela). Palaios, 24:59-69. http://dx.doi.org/ 10.2110/palo.2008.p08-004r

Lara-Ruiz, P.and Chiarello, A.G. 2005. Life-history traits and sexual dimorphism of the Atlantic forest maned sloth Bradypus torquatus (Xenarthra: Bradypodidae). Journal of Zoology, 267:63-73. https://doi.org/10.1017/S0952836905007259

Latham, J. and Davies, H. 1795. Faunula indica, p. 38. In Forster, J.R. (ed.), Zoologia indica (second edition). Gebaue, Halle.

Linnaeus, C. 1758. Systema Naturae, Ed. X. (Systema naturae per regna tria naturae, secundum classes, ordines, genera, species, cum characteribus, differentiis, synonymis, locis. Volumen I: Regnum animale. Editio decima, reformata. $10 \mathrm{i}$-ii + 1-824.

Lund, P.W. 1842. Blik paa Brasiliens dyreverden for sidste jordomvaeltning. Fjerde afhandling: fortsaettelse af pattedyrene. Det Kongelige Danske Videnskabernes Selskabs Skrifter: Naturvidenskabelige og Mathematiske Afhandlinger, 9:137-208.

McDonald, H.G. 1995. Gravigrade Xenarthrans from the early Pleistocene Leisey Shell Pit 1A, Hillsborough County, Florida. Bulletin Florida Museum of Natural History, 37:345-373.

McDonald, H.G. 2005. Paleoecology of extinct xenarthrans and the Great American Biotic Interchange. Bulletin Florida Museum of Natural History, 45:319-340.

McDonald, H.G. 2006. Sexual dimorphism in the skull of Harlan's ground sloth. Contributions in Science, Natural History Museum of Los Angeles County, 510:1-9.

McDonald, G.H. and Lundelius Jr., E.L. 2009. The giant ground sloth Eremotherium laurillardi (Xenarthra, Megatheriidae). In Albright III, L.B. (ed.), Papers on geology, vertebrate paleontology, and biostratigraphy in honor of Michael O. Woodburne. Museum of Northern Arizona Bulletin, 65:407-421.

Mihaljević M., Klug C., Aguilera O., Lüthi T., and Sánchez-Villagra M. R. 2010 Palaeodiversity of Caribbean echinoids including new material from the Venezuelan Neogene. Palaeontologia Electronica 13(3):20A:36p.

Ministerio de Energía y Minas. 1997. Léxico estratigráfico de Venezuela (Tercera Edición). Ministerio de Energía y Minas, Boletín de Geología, 12.

Miño-Boilini, A.R. and Zurita, A.E. 2015. Dimorphism in Quaternary Scelidotheriinae (Mammalia, Xenarthra, Phyllophaga). Palaeontologia Electronica 18.1.12A: 1-16. https://doi.org/ $10.26879 / 434$

Pujos, F. and Salas, R. 2004. A new species of Megatherium (Mammalia: Xenarthra: Megatheriidae) from the Pleistocene of Sacaco and Tres Ventanas, Peru. Palaeontology, 47:579-604. https://doi.org/10.1111/j.0031-0239.2004.00376.x

Quiroz, L.I. and Jaramillo, C.A. 2010. Stratigraphy and sedimentary environments of Miocene shallow to marginal marine deposits in the Urumaco Trough, Falcón Basin, Western Venezuela, p. 153-172. In Sánchez-Villagra, M.R., Aguilera, O.A., and Carlini, A.A. (eds.), Urumaco and Venezuelan Paleontology - the Fossil Record of the Northern Neotropics. Indiana University Press, Bloomington and Indianapolis.

Rovereto, C. 1914. Los estratos araucanos y sus fósiles. Anales del Museo Nacional de Historia Natural de Buenos Aires, 25:1-250.

Sánchez-Villagra, M.R., Aguilera, O.A., Sánchez, R., and Carlini, A.A. 2010. The fossil vertebrate record of Venezuela of the last 65 million years, p. 19-51. In Sánchez-Villagra, M.R., Aguilera, O.A., and Carlini, A.A. (eds.), Urumaco and Venezuelan Paleontology - the Fossil Record of the Northern Neotropics. Indiana University Press, Bloomington and Indianapolis.

Scheyer, T.M., Aguilera, O.A., Delfino, M., Fortier, D.C., Carlini, A.A., Sánchez, R., CarrilloBriceno, J.D., Quiroz, L., and Sánchez-Villagra, M.R. 2013. Crocodylian diversity peak and extinction in the late Cenozoic of the northern Neotropics. Nature Communications, 4:1907. https://doi.org/10.1038/ncomms2940

Scillato-Yané, G.J., Carlini, A.A., Tonni, E.P., and Noriega, J.I. 2005. Palaeobiogeography of the late Pleistocene pampatheres of South America. Journal of South American Earth Sciences, 20:131-138. https://doi.org/10.1016/j.jsames.2005.06.012

Solórzano, A., Rincón, A.D., and McDonald, H.G. 2015. A new mammal assemblage from the late Pleistocene El Breal de Orocual, northeast of Venezuela, p. 125-150. In Harris, J.M. (ed.), La Brea and Beyond: The Paleontology of Asphalt-Preserved Biotas, Science Series. Natural History Museum of Los Angeles County, Los Angeles. 
Spillmann, F. 1948. Beiträge zur Kenntnis eines neuen gravigraden Riesensteppentieres (Eremotherium carolinense gen. et. spec. nov.), seines Lebensraumes und seiner Lebensweise. Palaeobiologica, 8:231-279.

Tito, G. 2008. New remains of Eremotherium laurillardi (Lund, 1842) (Megatheriidae, Xenarthra) from the coastal region of Ecuador. Journal of South American Earth Sciences, 26:424-434. https://doi.org/10.1016/j.jsames.2008.05.001

Vucetich, M.G., Carlini, A.A., Aguilera, O.A., and Sánchez-Villagra, M.R. 2010. The Tropics as reservoir of otherwise extinct mammals: the case of rodents from a new Pliocene faunal assemblage from northern Venezuela. Journal of Mammalian Evolution, 17:265-273. https:// doi.org/10.1007/s10914-010-9142-x

White, J.L. and MacPhee, R.D.E. 2001. The sloths of the West Indies: a systematic and phylogenetic review. In Woods, C.A. and Sergile, F.E. (eds.), Biogeography of the West Indies: Patterns and Perspective. Boca Raton (LA), CRC Pres, p. 201-236.

Woodburne, M. 2010. The Great American Biotic Interchange: dispersals, tectonics, climate, sea level and holding pens. Journal of Mammalian Evolution, 17:245-264. https://doi.org/ 10.1007/s10914-010-9144-8

Zurita, A.E., Oliveira, E.V., Toriño, P., and Krapovickas, J. 2011. On the taxonomic status of some Glyptodontidae (Mammalia, Xenarthra, Cingulata) from the Pleistocene of South America. Annals of Paleontology, 97:63-83. 